\title{
СООТВЕТСТВУЮТ ЛИ РОССИЙСКИЕ ВЫБОРЫ СВОЕМУ КОНСТИТУЦИОННОМУ ПРЕДНАЗНАЧЕНИЮ
}

\begin{abstract}
Аннотация: Обсуждается состояние института выборов в России после двадиатилетнего развития в рамках действующей Конституции РФ. Отмечено, что избирательное законодательство не только крайне нестабильно, но и не имеет единого вектора, отличается метаниями из одной крайности в другую; при этом изменения обычно носят конъюнктурный характер. Показано, что активность избирателей имеет тенденцию к снижению, и в ряде регионов, а также во многих крупных городах показатели активности избирателей на региональных и муниципальных выборах крайне низки. Данные факты свидетельствуют о низком доверии граждан к институту выборов; об этом же говорят и результаты сочиологических опросов. В качестве основных дефектов в практике проведения выборов отмечаются недопуск к выборам популярных кандидатов и партийных списков, а также фальсификачии в ходе голосования и подсчета голосов. Кроме того, в последние годы благодаря определенным положениям избирательного законодательства частым становится явление «сфабрикованного больиинства», когда партия-лидер, получив менее половины голосов, добивается более половины мандатов. Делается вывод, что российские выборы в основном не соответствуют своему конституционному предназначению - быть высшим непосредственным выражением власти народа

Abstract: The author analyzes the current position of the institution of elections in Russia after the two decades of its development within the framework of the current Constitution of the Russian Federation. It is noted that the election legislation is not stable, it lacks a united vector, it moves to one extremity and then to the other, and the changes are conjuncture-based. It is shown that the elector activities are lowering, and in many regions and large cities the number of active electors in regional and municipal elections is extremely low. These facts show low level of trust of electors to the institution of elections, and the social polls show the same tendency. The main defects in the practice of elections included preclusion of access to elections for popular candidates and party lists, and falsifications in counting elector voices. Additionally, due to some provisions of current election legislation of late year a new problem of "fabricated majority" takes place more and more often. The conclusion is made that the Russian elections mostly do not correspond to their constitutional purpose, which is to express the will of the people.

Ключевые слова: выборы, избирательное законодательство, активность избирателей, доверие граждан, регистрачия кандидатов, фальсификаиии, избирательная система, сфабрикованное большинство, избирательная реформа, Избирательный кодекс
\end{abstract}

Keywords: elections, election legislation, activities of electors, trust of citizens, registration of candidates, falsification, election system, fabricated majority, election reform, Election Code.

V нститут российских выборов ненамного старше действующей российской Конституции. Разумеется, можно вспоминать и выборы Земских соборов в феодальной России, и выборы Государственной думы 1906-1912 годов, и выборы в Учредительное собрание 1917 года, а также те ритуальные мероприятия, которые назвались выборами в советский период. Но по сути создание института подлинных выборов началось в России, как и во всех советских республиках, практически с нуля в 1989 году. Важными вехами на этом пути были выборы народных депутатов СССР 1989 года, выборы народных депутатов РСФСР и местных Советов 1990 года, выборы Президента РСФСР 1991 года.
12 декабря 1993 года одновременно со всенародным голосованием по проекту Конституции РФ прошли выборы Государственной Думы и Совета Федерации (а также выборы законодательных органов 10 субъектов РФ). Эти выборы были проведены по новым правилам, которые в основном закрепились в последующие годы, и потому можно утверждать, что в 1993 году одновременно с конституционной реформой была проведена реформа избирательной системы'.

\footnotetext{
${ }^{1}$ См.: Иванченко А.В., Любарев А.Е. Российские выборы от перестройки до суверенной демократии. М., 2007; Кынев А.В., Любаpeв A.E. Партии и выборы в современной России: Эволюция и деволюция. М., 2011.
} 
DOI: $10.7256 / 1811-9018.2013 .13 .10158$

При цитировании этой статьи сноска на dоі обязательна

\section{Право и политика $13(168) \cdot 2013$}

Конституция Российской Федерации 1993 года определила свободные выборы наряду с референдумом как высшее непосредственное выражение власти народа. На протяжении последующих 20 лет избирательная система России претерпела множество разнонаправленных изменений. И сегодня уместно поставить вопрос: выполняет ли институт выборов в России ту функцию, то предназначение, которые провозглашены в Конституции? Попытке ответить на этот вопрос и посвящена настоящая статья.

\section{Избирательное законодательство}

За последние 20 лет было принято около ста федеральных законов, касающихся избирательного законодательства ${ }^{2}$. Однако в разные годы процесс принятия законов о выборах и их изменения сильно различался как по форме, так и по содержанию.

В 1990-е годы шло становление нового российского избирательного законодательства. Избирательная реформа 1993 года была осуществлена указами Президента РФ. В 1994-1995 годах были приняты федеральные законы «Об основных гарантиях избирательных прав граждан Российской Федерации» («рамочный» закон), «О выборах Президента Российской Федерации» и «О выборах депутатов Государственной Думы Федерального Собрания Российской Федерации». На основании этих законов прошли выборы депутатов Государственной Думы в 1995 году и выборы Президента РФ в 1996 году, а также региональные и муниципальные выборы в большинстве субъектов РФ.

В 1997-1999 годах были приняты новые версии всех трех основных избирательных законов (при этом «рамочный» закон стал именоваться «Об основных гарантиях избирательных прав и права на участие в референдуме граждан Российской Федерации»), однако основные принципы и положения в этих законах остались неизменными. Изменения были направлены в основном на большую детализацию и регламентацию избирательных процедур, на устранение пробелов, на предотвращение злоупотреблений со стороны различных участников выборов с учетом опыта прошедших кампаний ${ }^{3}$. Такой подход критиковался некоторыми

\footnotetext{
${ }^{2}$ См.: Любарев А.Е. Хронология изменений российского избирательного законодательства, 1988-2013 // Сайт Центра «Геликс» (http://www.geliks.org/index.php?option=com_content\&task=view \&id=1558\&Itemid $=431$ ).

${ }^{3}$ См.: Шейнис В.Л. Избирательное законодательство и избирательная практика в системе российских государственных институтов // Конституционный вестник. 2008. № 1 (19). С. 214-230.
}

правоведами ${ }^{4}$, но он был, по-видимому, оправдан: в условиях низкой правовой культуры детальная регламентация процедур необходима. Единственной, пожалуй, крупной ошибкой законодателей в те годы стал широкий и открытый перечень оснований для отказа в регистрации кандидатов, а также для отмены их регистрации (к тому же право отмены регистрации было оставлено избирательным комиссиям, которые, таким образом, превратились в квази-судебные органы). Это в конце 1990-х и начале 2000-х годов привело к широкому распространению технологии снятия с выборов кандидатов, неугодных для региональной или местной власти ${ }^{5}$.

В 2002-2003 годах вновь произошла «работа над ошибками», и были приняты новые версии трех основных избирательных законов. В частности, перечни оснований для отказа в регистрации и отмены регистрации были сокращены и сделаны закрытыми, избирательные комиссии были лишены права отменять регистрацию в качестве санкций за нарушение закона, однако эти меры уже не смогли остановить поднявшуюся волну «зачисток» избирательных бюллетеней от неугодных кандидатов.

В те годы ключевую роль в работе над избирательным законодательством играли ЦИК РФ и ее председатель (а ранее - секретарь) А.А. Вешняков. В одном из интервью 2002 года он провозгласил, что в избирательное законодательство вносится «последнее серьезное изменение» и далее оно будет стабильным ${ }^{6}$. Однако произошло обратное: изменения стали нарастать как снежный ком. В 2002-2005 годах было принято 10 федеральных законов, внесших изменения во вновь принятый Федеральный закон «Об основных гарантиях избирательных прав и права на участие в референдуме граждан Российской Федерации». А затем правка этого закона осуществлялась уже непрерывно: в 2006 году - 5 федеральных законов, в $2007-6$, в $2008-6$, в $2009-8$, в $2010-7$, в $2011-8$, в 2012 -5 , в 2013 (по ноябрь) -6 . Итого 51 изменение за неполных

\footnotetext{
${ }^{4}$ См.: Постников А.Е. Новый проект Федерального закона «Об основных гарантиях избирательных прав и права на участие в референдуме граждан Российской Федерации»: минусы и плюсы // Материалы «круглого стола» по обсуждению законопроекта «О внесении изменений и дополнений в Федеральный закон «Об основных гарантиях избирательных прав и права на участие в референдуме граждан Российской Федерации». М., 2002. С. 6-25.

${ }^{5}$ См.: Прибыловский В. Управляемые выборы: Деградация выборов при Путине // Россия Путина: История болезни. М., 2004. С. 6-85; Кынев А.В., Любарев А.Е. Партии и выборы в современной России: Эволюция и деволюция. М., 2011.

${ }^{6}$ См.: Вешняков А.А. Централизация нужна для защиты демократии // Коммерсантъ-Власть. 2002. 2 июля. С. 27.
} 
8 лет. Также непрерывным изменениям подвергались федеральные законы о выборах депутатов Государственной Думы и Президента РФ.

Но дело не только в количестве изменений. В 2004-2007 годах ревизии подверглось большинство базовых положений избирательного законодательства, которые сложились в 1990-е годы. Так, в эти годы были осуществлены следующие изменения:

- отменены прямые выборы глав регионов;

- $\quad$ введена полностью пропорциональная избирательная система на выборах в Государственную Думу и началось внедрение этой системы на региональных и муниципальных выборах;

- повышен с 5 до 7\% заградительный барьер на выборах в Государственную Думу и почти повсеместно - на региональных выборах;

- у увеличено с 7 до 100 минимальное число региональных групп, на которые должен разбиваться партийный список на выборах в Государственную Думу;

- уменьшено с 18 до 3 максимальное число кандидатов в центральной части списка на выборах в Государственную Думу;

- отменен институт избирательных блоков, а затем партиям было запрещено выдвигать членов других партий;

- $\quad$ введены два единых дня голосования - весенний (в марте) и осенний (в октябре, а в год выборов в Государственную Думу - в декабре);

- $\quad$ ужесточены нормы, связанные с регистрацией кандидатов и партийных списков (уменьшены с 25 до 5-10\% допустимая доля брака в подписных листах и допустимый избыток представляемых подписей; запрещено одновременно представлять подписи и вносить залог; введено требование нотариального заверения подписей сборщиков);

- $\quad$ отменено право общественных объединений направлять наблюдателей на избирательные участки;

- отменена возможность голосовать «против всех»;

- отменен порог явки;

- $\quad$ запрещена агитация против соперников на телеканалах;

- отменена обязанность высших чиновников, зарегистрированных в качестве кандидатов, уходить в отпуск;

- отменены санкции за отказ избранного кандидата от мандата;

- $\quad$ партийным руководителям предоставлено право менять очередность кандидатов в партсписках при замещении вакантных мандатов;
- $\quad$ введены дополнительные ограничения пассивного избирательного права (для граждан РФ, имеющих иностранное гражданство или вид на жительство в иностранном государстве; для граждан, попавших под широкое определение «экстремизма»).

К этому следует добавить увеличение требования к численности политических партий (с 10 до 50 тыс.), приведшее к сокращению числа партий с 46 до 77, существенное усложнение правил инициирования общероссийского референдума, а также запрет депутатам, избранным от партий, выходить из состава фракции, переходить в другие фракции и в другие партии.

Уже в 2005 году многие эксперты сделали вывод, что происходит контрреформа избирательного и смежного законодательства, направленная на усиление запретов и ограничений для самостоятельных субъектов избирательного процесса и одновременно на снятие ограничений для использования административного ресурса. И в целом российское избирательное законодательство отдаляется от соответствия международным демократическим стандартам ${ }^{8}$.

Эта тенденция, хотя и в меньших масштабах, продолжала действовать и в последующие годы. Так, в 2009 году была отменена возможность регистрироваться на основании избирательного залога, и тогда же непартийные общественные объединения были лишены права выдвигать списки кандидатов на муниципальных выборах. В 2012 году граждане, осужденные когда-либо за преступления, отнесенные к тяжким или особо тяжким, были пожизненно лишены пассивного избирательного права. В конце 2012 года два единых дня голосования были заменены на один, причем в крайне неудобное время - второе воскресенье сентября.

Однако в конце 2008 года наметилась тенденция уже по пересмотру некоторых новелл 2004-2007 годов. Вначале изменения были очень робкими: минимальную численность партий снизили в два этапа до 40 тыс., что не могло сыграть существенной роли; вместо возврата 5\%ного барьера были введены один-два «утешительных» мандата для партий, получивших от 5 до 7\%. Но уже в 2011 году барьер все же решили снизить до 5\%, а после массовых митингов, прошедших зимой 2011-2012 годов,

\footnotetext{
${ }^{7}$ См.: Любарев А.Е. Является ли численность партии индикатором ее общественной поддержки // Право и политика. 2010. № 3. С. 462-469.

${ }^{8}$ См.: Российские выборы в контексте международных избирательных стандартов: Материалы международной конференции / Под ред. А.В. Иванченко, А.Е. Любарева. М., 2006.
} 
DOI: $10.7256 / 1811-9018.2013 .13 .10158$

При цитировании этой статьи сноска на dоі обязательна

\section{Право и политика $13(168) \cdot 2013$}

минимальную численность партий снизили сразу до 500 человек, и восстановили выборы глав регионов (правда, с менее демократичными правилами). Одновременно все партии были освобождены от сбора подписей избирателей в поддержку выдвинутых ими кандидатов и списков.

Внедрение полностью пропорциональной системы на региональных и муниципальных выборах достигло пика в 2009-2010 годах, а затем начался обратный процесс - в некоторых регионах и городах от нее отказались. И в 2013 году в первом чтении принят законопроект, восстанавливающий смешанную систему на выборах в Государственную Думу. В конце 2013 года было пересмотрено в пользу увеличения мажоритарной части существовавшее с 2003 года соотношение пропорциональной и мажоритарной частей на региональных выборах и отменено введенное в 2011 году требование об обязательном использовании пропорциональной компоненты на муниципальных выборах в крупных городах и районах.

Минимальное число региональных групп на выборах в Государственную Думу еще в 2007 году было снижено со 100 до 80; в 2011 году его снизили до 70, а в законопроекте, принятом в 2013 году в первом чтении, предлагается его снизить до 35. Максимальное число кандидатов в центральной части списка в 2010 году увеличено до 10.

Уже внесен в Государственную Думу законопроект, предусматривающий восстановление голосования «против всех», обсуждается возможность пересмотра совсем недавно принятого решения о допуске на выборы всех партий без сбора подписей избирателей и/ или о новом повышении планки численности партий.

Таким образом, избирательное законодательство не только крайне нестабильно, но и не имеет единого вектора, отличается метаниями из одной крайности в другую. При этом изменения обычно носят конъюнктурный характер, что лучше всего видно на примере перехода от смешанной системы к пропорциональной и обратно. Когда в связи с временным уходом В.В. Путина с поста Президента РФ требовалось усилить его контроль над депутатским корпусом, смешанную систему заменили на пропорциональную. Но снижение результата «Единой России» вынудило вернуть смешанную систему, которая позволяет партии-лидеру получать большинство мандатов даже при поддержке всего около трети избирателей. С этими же мотивами связано и резкое увеличение числа участвующих в выборах партий.

Не отличается стабильностью и региональное избирательное законодательство. В значительной степени это связано с необходимостью постоянно приводить его в соответствие с изменяющимся «рамочным» федеральным законом. Однако есть ряд вопросов, в которых федеральный законодатель оставляет региональному относительную свободу маневра (в первую очередь это касается параметров избирательной системы в узком смысле этого понятия), и в этих вопросах мы также видим нестабильность и конъюнктурную правку9.

Выше уже отмечалось, что на региональном и муниципальном уровнях также происходили переходы от смешанной системе к пропорциональной и обратно (а сейчас намечается возврат к мажоритарной системе). Стоит отметить все большее применение при распределении мандатов на региональных и муниципальных выборах метода делителей Империали, не отвечающего критериям пропорционального распределения ${ }^{10}$, а также принуждение к разбиению партийных списков на неоправданно большое число территориальных групп.

Характерно также, что обычно изменения региональных законов, затрагивающие избирательную систему, происходят незадолго до начала избирательной кампании (часто менее чем за месяц до ее начала), что затрудняет для потенциальных участников выборов подготовку к ним и противоречит рекомендациям Европейской комиссии «За демократию через право» не пересматривать избирательную систему менее чем за год до выборов ${ }^{11}$.

При этом региональные законы отличаются низким качеством, в них часто содержатся пробелы и ошибки, особенно в методике распределения мандатов ${ }^{12}$, и уже не раз избирательным комиссиям приходилось принимать решение о распределении мандатов, не основанное на положениях регионального закона.

Положения избирательного законодательства довольно часто подвергаются проверке на предмет их конституционности. С 1998 по 2013 год Конституционный Суд РФ 10 раз признавал не соответствующими Конституции РФ положения федеральных законов о

\footnotetext{
${ }^{9}$ См.: Любарев А.Е. Регулирование избирательной системы в законодательстве субъектов Российской Федерации // Российский юридический журнал. 2010. № 4. С. 76-82.

${ }^{10}$ См.: Любарев А.Е., Шалаев Н.Е. О критерии пропорциональности при распределении мандатов между партийными списками // Конституционное и муниципальное право. 2009. № 23. С. 23-27.

${ }^{11}$ См.: Свод рекомендуемых норм при проведении выборов. Руководящие принципы и пояснительный доклад // Международные избирательные стандарты: Сборник документов. М., 2004. С. 630.

${ }^{12}$ См.: Любарев А.Е. Регулирование избирательной системы, применяемой на муниципальных выборах, в законах субъектов РФ // Муниципальная Россия. 2011. № 8. С. 57-70.
} 
выборах ${ }^{13}$ и 4 раза - региональных ${ }^{14}$. Последнее решение Конституционного Суда касается введенного полтора года назад пожизненного лишения пассивного избирательного права осужденных лиц. Стоит отметить, что Государственная Дума до сих пор не внесла в законодательство изменения по реализации Постановления Конституционного Суда РФ от 22 июня 2010 года № 14-П, признавшее неконституционным лишение гражданина РФ, получившего вид на жительство на территории иностранного государства, возможности быть членом территориальной избирательной комиссии с правом решающего голоса (при том, что Конституционный Суд сознательно ограничил предмет рассмотрения, не затронув не только пассивное избирательное право граждан, но даже их право быть членами других избирательных комиссий).

\section{Доверие к выборам и активность избирателей}

В недавней работе автор проанализировал активность избирателей на федеральных, региональных и муниципальных выборах ${ }^{15}$. Было показано, что основной тенденцией является снижение явки, однако во второй половине 2000-х годов наблюдалось некоторое ее повышение. Это повышение, как показал анализ, было достигнуто в основном административными методами, хотя для региональных выборов определенную роль сыграл переход от мажоритарной избирательной системы к смешанной.

Существенными являются различия в уровне активности по видам выборов, а также по регионам. Что касается вида выборов, то в основном сложилась следующая шкала убывания активности избирателей: выборы Президента РФ, выборы Государственной Думы, выборы главы региона, выборы регионального парламента, выборы главы муниципального образования, выборы представительного органа муниципального образования. Разумеется, на данной шкале довольно много исключений, особенно часто таким исключением является более высокая явка на выборах главы регио-

\footnotetext{
${ }^{13}$ См.: постановления Конституционного Суда РФ от 17.11.1998 № 26-П, от 25.04.2000 № 7-П, от 15.01.2002 № 1-П, от 11.06.2002 № 10-П, от 30.10.2003 № 15-П, от 25.02.2004 № 4-П, от 14.11.2005 № 10-П, 22.6.2010 № 14-П, 22.04.2013 № 8-П, 10.10.2013 № 20-П.

${ }^{14}$ См.: постановления Конституционного Суда РФ от 23.03.2000 № 4-П, от 22.01.2002 № 2-П, от 11.03.2008 № 4-П, от 07.07.2011 № 15 -П.

${ }^{15}$ См.: Любарев А.Е. Активность избирателей на федеральных, региональных и муниципальных выборах в Российской Федерации // NB: Проблемы общества и политики. 2013. № 8. С.138-209.
}

на или муниципального образования по сравнению с выборами соответственно в Государственную Думу или региональный парламент. Тем не менее, общая тенденция налицо.

Если же говорить о субъектах РФ, то заметен сильный контраст между регионами, которые относят к «электорально управляемым» (большинство республик Северного Кавказа и Поволжья, Ямало-Ненецкий и Чукотский автономные округа, Кемеровская, Тюменская и некоторые другие области) ${ }^{16}$ и большей частью краев и областей. Так, на выборах депутатов Государственной Думы 2011 года явка в Чеченской Республике составила 99,5\%, а в Иркутской области 47,1\%. На выборах региональных парламентов рекорды высокой явки также у Чеченской Республики $(99,5 \%$ в 2009 году, 92,0\% в 2013 году). Рекорд низкой явки для выборов, проводимых по пропорциональной или смешанной системам, несколько лет держала Свердловская область (27,9\% в 2006 году), в октябре 2012 года этот рекорд побила Сахалинская область (27,5\%), но в сентябре 2013 года более низкую явку показали Архангельская $(25,2 \%)$ и Иркутская $(25,3 \%)$ области ${ }^{17}$.

На муниципальных выборах обнаруживается тенденция: в сельских поселениях активность избирателей в целом заметно выше, чем в городских. В исследованной нами выборке средние значения явки таковы: для выборов глав сельских поселений $-55,3 \%$, для выборов представительных органов сельских поселений $-49,0 \%$, для выборов глав городских поселений $-34,8 \%$, для выборов представительных органов городских поселений - 34,3\%. В целом, особенно если отбросить специфические регионы, можно сказать, что на выборах глав сельских поселений скорее нормой, чем исключением, является явка ниже 50\%, на выборах представительных органов сельских поселений - ниже $40 \%$, на выборах глав городских поселений - ниже $30 \%$, а на выборах представительных органов городских поселений - ниже $20 \%{ }^{18}$.

В городских округах, особенно в административных центрах регионов, активность избирателей зача-

\footnotetext{
${ }^{16}$ См.: Орешкин Д.Б. Электоральная демократия и целостность политического пространства России // Журнал о выборах. 2001. № 2. C. 28-33.

${ }^{17}$ См.: Кынев А., Любарев А., Максимов А. Аналитический обзор № 4 по мониторингу избирательной кампании 8 сентября 2013: рождение новой парадигмы выборов // Сайт Комитета гражданских инициатив, 16.09.2013 (http://komitetgi.ru/analytics/848/).

${ }^{18}$ См.: Любарев А.Е. Активность избирателей на федеральных, региональных и муниципальных выборах в Российской Федерации // NB: Проблемы общества и политики. 2013. № 8. С.138-209.
} 


\section{Право и политика $13(168) \cdot 2013$}

стую еще ниже. Так, на выборах главы Архангельска в 2008 году явка составила 18,3\%, главы Омска в 2012 году - 17,3\%, главы Владивостока в 2013 году - 18,6\%, представительных органов Петропавловска-Камчатского и Владивостока в 2012 году - соответственно 16,6 и 13,1\%, Красноярска и Тюмени в 2013 году - соответственно 18,6 и $17,3 \%$.

Уже региональные и муниципальные выборы, прошедшие 14 октября 2012 года, показали явную тенденцию к снижению активности избирателей. Тем не менее, в это время было принято решение о переносе единого дня голосования с октября на сентябрь. И, как и предсказывали эксперты, это привело к еще большему снижению показателей явки.

Такие показатели активности избирателей сами по себе свидетельствуют о низком доверии граждан к институту выборов. Этот вывод подкрепляется и данными социологических опросов. Так, исследование, проведенное в июле 2013 года Левада-центром, показало самый низкий уровень доверия к выборам за последние полтора года. $61 \%$ опрошенных выразил мнение, что на предстоящих сентябрьских выборах «будет лишь имитация борьбы, а победы и распределение мест в законодательных органах власти будут определены по решению властей», и лишь 26\% считали, что «будет происходить реальная борьба за власть». 57\% опрошенных сказали, что предстоящие выборы будут «скорее «грязными» (с использованием клеветы, нажима на избирателей, махинаций с избирательными бюллетенями и т.п.)», в то время как только 25\% полагали, что они будут «в целом честными, законными» ${ }^{19}$.

\section{Отсеивание кандидатов и партий на стадии регистрации}

Конституционный Суд РФ неоднократно отмечал, что законодатель, устанавливая порядок выдвижения и регистрации кандидатов, вправе в интересах избирателей предусмотреть специальные предварительные условия, позволяющие исключить из избирательного процесса тех его участников, которые не имеют достаточной поддержки избирателей ${ }^{20}$. Соглашаясь с

\footnotetext{
19 См.: Солянская K. Выборы смешали с грязью // Газета.ру, 03.08.2013 (http://www.gazeta.ru/politics/2013/08/03_a_5539681. shtml); Россияне о выборах в региональные и местные органы власти // Сайт Левада-центра, 03.08.2013 (http://www.levada.ru/03-082013/rossiyane-o-vyborakh-v-regionalnye-i-mestnye-organy-vlasti).

${ }^{20}$ См., например: Постановление Конституционного Суда РФ от 17.11.1998 № 26-П // Собрание законодательства РФ. 1998. № 48. Ст. 5969.
}

такой позицией, мы должны признать, что указанные специальные предварительные условия, включающие и основания для отказа в регистрации, должны быть направлены исключительно на проверку того, имеет ли кандидат достаточную поддержку избирателей. Иное неизбежно будет приводить к несоразмерному ограничению пассивного избирательного права граждан и допускать возможность для привилегий либо ограничений дискриминационного характера ${ }^{21}$. Отметим также, что отказ в регистрации кандидата, имеющего достаточную поддержку избирателей, ограничивает не только его пассивное избирательное право, но и активное избирательное право поддерживающих его избирателей.

К сожалению, со второй половины 1990-х годов российские выборы постоянно демонстрируют случаи отказов в регистрации либо отмены регистрации популярных кандидатов и списков кандидатов популярных избирательных объединений ${ }^{22}$. Это происходит как вследствие явно неудачных норм избирательного законодательства, так и его тенденциозного применения. При этом стоит отметить, что плохое законодательство и репрессивная направленность его применения создают кумулятивный эффект. Неудачно сформулированные нормы закона, по сути, провоцируют правоприменителей принимать решения, нарушающие избирательные права граждан. В результате основаниями для отказов в регистрации становятся мелкие недостатки в подписных листах, не связанные с их фальсификациями и не свидетельствующие о том, что избиратели не ставили свои подписи в этих листах, а также другие недостатки в оформлении документов, не имеющие отношения к вопросу о серьезности кандидата и несоразмерные принимаемому решению об отказе в регистрации.

\footnotetext{
${ }^{21}$ Согласно пункту 6 статьи 9 Конвенции о стандартах демократических выборов, избирательных прав и свобод в государствах - участниках Содружества Независимых Государств, подлинные выборы предполагают равные и справедливые правовые условия для регистрации кандидатов, списков кандидатов и политических партий (коалиций); регистрационные требования должны быть ясными и не содержать условий, способных стать основанием для привилегий либо ограничений дискриминационного характера.

${ }^{22}$ См.: Прибыловский В. Управляемые выборы: Деградация выборов при Путине // Россия Путина: История болезни. М., 2004. С. 6-85; Российские выборы в контексте международных избирательных стандартов: Материалы международной конференции / Под ред. А.В. Иванченко, А.Е. Любарева. М., 2006. С. 65-76, 264-268, 278-281; Любарев А.Е. Обеспечивает ли российское законодательство свободную конкуренцию на выборах? // Журнал о выборах. 2006. № 2. С. 53-57; Любарев А.Е. Препятствия для свободной конкуренции на выборах: законодательство и правоприменительная практика // Российское электоральное обозрение. 2007. № 1. C. 20-28.
} 
Впечатляют даже формальные показатели. В пункте 6.4 статьи 38 Федерального закона «Об основных гарантиях избирательных прав и права на участие в референдуме граждан Российской Федерации» содержатся 14 подпунктов, перечисляющих основания для признания подписи избирателя недействительной (при этом следует отметит, что имеются в виду не фальшивые подписи, так как последние именуются недостоверными); в пункте 24 этой же статьи 18 подпунктов, перечисляющих основания для отказа кандидату в регистрации; в пункте 25 - 15 подпунктов, перечисляющих основания для отказа в регистрации списка кандидатов; в пункте 26 - 10 подпунктов, перечисляющих основания для исключения кандидата из заверенного списка кандидатов; следует также отметить, что некоторые из этих подпунктов содержат сразу несколько оснований.

Главной причиной отсева является проверка подписных листов. Ситуациюусугубила отмена в 2009 году избирательного залога - кандидаты и партии лишились альтернативного способа регистрации. Статистика красноречива: на региональных выборах, проходивших в единые дни голосования 10 октября 2010 года, 13 марта 2011 года и 4 декабря 2011 года, отсев при регистрации в одномандатных округах кандидатов, выдвинутых парламентскими партиями (которым не требовалось представлять в свою поддержку подписи избирателей), составлял 1,3-1,6\%, кандидатов, выдвинутых непарламентскими партиями, $-58-60 \%$, самовыдвиженцев - 40-47\%. После того, как в 2012 году кандидаты от непарламентских партий были освобождены от представления подписей избирателей, их показатели кардинально изменились: на выборах 14 октября 2012 года их отсев составил 4,8\%, на выборах 8 сентября 2013 года $-8,9 \%$. При этом показатели других кандидатов изменились мало: у кандидатов от парламентских партий отсев на выборах 14 октября 2012 года составил 3,3\%, а на выборах 8 сентября 2013 года - 3,4\%; у самовыдвиженцев отсев на выборах 14 октября 2012 года составил 40,5\%, а на выборах 8 сентября 2013 года $-47,5 \%{ }^{23}$.

Ситуация с отсевом самовыдвиженцев требует отдельного комментария. Дело в том, что в 2012 году были существенно снижены требования к числу подписей избирателей: если раньше региональные законы требовали представлять подписи в количестве 1 или

${ }^{23}$ См.: Любарев A.E. Первые итоги партийной и избирательной реформ 2012 года // Сайт Комитета гражданских инициатив, 14.01.2013 (http://komitetgi.ru/analytics/490/).
$2 \%$ от числа избирателей соответствующего округа, то теперь федеральный закон ограничил этот показатель сверху 0,5\%. Но, как видим, это не привело к снижению уровня отсева. И данный факт является красноречивым доказательством того, что чрезмерны не требуемое количество подписей, а нормы по их проверке и «выбраковке» (в том числе норма об отказе в регистрации при обнаружении более $5 \%$ недействительных подписей). Добавим, что на выборах представительных органов городов - административных центров регионов ситуация еще критичнее: на выборах 14 октября 2012 года отсев среди самовыдвиженцев составил 73\%, на выборах 8 сентября 2013 года $-55 \%$.

Однако и в тех случаях, когда не требуется представление подписей, уровень отсева не столь уж мал. Выше отмечалось, что на выборах региональных парламентов 8 сентября 2013 года отсев среди кандидатов от парламентских партий составил $3,4 \%$, а среди кандидатов от непарламентских партий $-8,9 \%$. На этих же выборах отсев среди списков кандидатов на стадии регистрации составил $8,5 \%$. А ведь этот отсев связан исключительно с оформлением документов, требуемых от кандидатов и партий.

Стоит отметить также немалое число случаев отмены регистрации популярных кандидатов на региональных и муниципальных выборах, прошедших 8 сентября 2013 года ${ }^{24}$.

А вот правила регистрации кандидатов на президентских выборах, действовавшие в 2004, 2008 и 2012 годах, - это как раз тот случай, когда требуемое число подписей (2 млн.) чрезмерно. Впрочем, на этих выборах для непартийных кандидатов действует еще один фильтр - собрание избирателей численностью не менее 500 человек, через который на выборах 2008 года смогли пройти лишь два кандидата из 29. В том же 2008 году на основании подписей избирателей смог зарегистрироваться только один кандидат (А.В. Богданов), который в итоге получил всего 968 тыс. голосов, то есть более чем вдвое меньше представленных подписей, в то время как отказ в регистрации получил бывший председатель Правительства РФ М.М. Касьянов ${ }^{25}$. В 2012 году по

\footnotetext{
${ }^{24}$ См.: Кынев А., Максимов А. Аналитический обзор. Агитационная кампания и подготовка к дню голосования 8 сентября 2013: косвенная агитация, спойлерские и «маскировочные технологии» против технологической революции // Сайт Комитета гражданских инициатив, 02.08.2013 (http://komitetgi.ru/analytics/827/).

${ }^{25}$ См.: Бузин А.Ю., Любарев А.Е. Преступление без наказания: Административные технологии федеральных выборов 2007-2008 годов. М., 2008. С. 70-82.
} 


\section{Право и политика $13(168) \cdot 2013$}

подписям удалось зарегистрироваться только миллиардеру М.Д. Прохорову, а отказы получили ветеран президентских выборов, основатель партии «Яблоко» Г.А. Явлинский и губернатор Иркутской области Д.Ф. Мезенцев ${ }^{26}$. При этом эксперты неоднократно высказывали сомнения в подлинности подписей, собранных зарегистрированными кандидатами в 2004, 2008 и 2012 годах.

Чрезмерность нормы в 2 млн. подписей фактически признал и Д.А. Медведев, который в декабре 2011 года внес законопроект, снижающий число подписей для кандидатов от непарламентских партий до 100 тыс., а для самовыдвиженцев - до 300 тыс. Однако это изменение еще не действовало на выборах 2012 года. Сомнительными с конституционной точки зрения являются и различия в требованиях для самовыдвиженцев, которые, как отмечалось выше, должны перед этим заручиться поддержкой не менее 500 избирателей, и кандидатов от партий, которым по новому закону достаточно иметь всего 500 членов.

Отдельного рассмотрения заслуживают восстановленные в 2012 году выборы глав регионов, для которых был специально придуман «муниципальный фильтр», причем в «трехслойном» варианте:

1. необходимо собрать определенный процент (от 5 до $10 \%$ по усмотрению регионального законодателя) от общего числа муниципальных депутатов и избранных на выборах глав;

2. в числе этих подписей должен быть определенный процент (от 5 до 10\% по усмотрению регионального законодателя) от общего числа депутатов представительных органов муниципальных районов и городских округов, а также избранных на выборах глав муниципальных районов и городских округов;

3. при этом кандидат должен получить подписи последних не менее чем в трех четвертях муниципальных районов и городских округов.

Кроме того, это единственные выборы, для которых региональный законодатель самостоятельно решает, допускать ли самовыдвижение. И из 83 регионов только в Москве самовыдвижение допущено, но с такими условиями, что зарегистрироваться в качестве самовыдвиженца удалось лишь действующему мэру.

Как показал наш анализ, кандидаты ни от одной из оппозиционных партий (кроме КПРФ, да и то не во

\footnotetext{
${ }^{26}$ См.: Кынев A.B. Подготовка к избирательной кампании. Выдвижение и регистрация кандидатов. Технологии предвыборной агитации // Выборы Президента России 4 марта 2012 года: Аналитический доклад. М., 2012. С. 8-80.
}

всех регионах) не способны пройти через «муниципальный фильтр» без подписей представителей «Единой России $2^{27}$. По сути это означает, что именно власть решает, кому позволить конкурировать с ее кандидатами. В некоторых регионах, например, в Москве, власть поступила либерально, оказав реальным конкурентам помощь в прохождении «муниципального фильтра», то есть применив административный ресурс для преодоления препятствий, поставленных федеральным законом. Однако это лишь доказывает неадекватность «муниципального фильтра». Примером другого рода служит Новгородская область, где «муниципальный фильтр» не смогли преодолеть кандидаты от КПРФ и «Справедливой России» - партий, которые 4 декабря 2011 года получили в этом регионе 19,5 и 28,1\% (к тому же оба кандидата - депутаты областной Думы), но зато его преодолел не имеющий широкой известности кандидат от «Патриотов России», хотя эта партия 4 декабря 2011 года довольствовалась в области $0,9 \%$ голосов.

\section{Проблема фальсификаций}

Фальсификации в процессе голосования и подсчета голосов имели место с самого начала новейшей истории российских выборов (то есть с 1989 года), но вплоть до 2007 года они, вопреки распространенным мифам, не носили массового характера ${ }^{28}$. Однако уже на федеральных выборах 2007-2008 годов информация о фальсификациях поступала из многих регионов. Эти факты дополнялись статистическим анализом официальных итогов голосования, которые показали, что на выборах депутатов Государственной Думы 2007 года из 44,7 млн. голосов, полученных «Единой Россией», 13,8 млн. следует признать «аномальными», а на выборах Президента РФ 2008 года «аномальными» были 14,8 млн. голосов из 52,5 млн., поданных за Д.А. Медведева ${ }^{29}$. По нашим оценкам, эти «аномальные» голоса могут быть объяснены либо

\footnotetext{
${ }^{27}$ См.: Любарев А.Е. Первые итоги партийной и избирательной реформ 2012 года // Сайт Комитета гражданских инициатив, 14.01.2013 (http://komitetgi.ru/analytics/490/); Кынев А., Любарев А., Максимов А. Второй доклад по мониторингу избирательной кампании 8 сентября 2013. Итоги регистрации кандидатов: между борьбой за легитимность и страхом утраты контроля // Сайт Комитета гражданских инициатив, 14.08.2013 (http://komitetgi.ru/analytics/788/).

${ }^{28}$ См.: Любарев А.Е., Бузин А.Ю., Кынев А.В. Мертвые души: Методы фальсификации итогов голосования и борьба с ними. M., 2007. C. 19-39.

${ }^{29}$ См.: Бузин А.Ю., Любарев А.Е. Преступление без наказания: Административные технологии федеральных выборов 2007-2008 годов. М., 2008.
} 
прямыми фальсификациями типа «вброса», либо несвободным голосованием значительной части избирателей. Наличие масштабных фальсификаций было подтверждено и другими методами ${ }^{30}$.

В то же время влияние столь масштабных фальсификаций на результаты выборов было, по нашим оценкам, не слишком существенным. Если исключить «аномальные» голоса, то «Единая Россия» получила бы в 2007 году 55,6\% голосов вместо 64,3\% и 278 мандатов вместо 315. Иными словами, она все равно имела бы в Государственной Думе абсолютное (но не квалифицированное) большинство. Д.А. Медведев без «аномальных» голосов получил бы $63,0 \%$ вместо 70,3\%, что позволяло ему быть избранным в первом туре.

Иная ситуация сложилась на выборах в Московскую городскую Думу в 2009 году. Согласно расчетам, «Единая Россия» без учета «аномальных» голосов получила бы 46\% вместо 66,2\%, и в городскую Думу прошли бы не две, а пять партий ${ }^{31}$.

Фальсификации на выборах в Государственную Думу 2011 года оказались столь беззастенчивыми (особенно в Москве), что вызвали волну протеста. На прошедших 10 и 24 декабря 2011 года массовых митингах в Москве были сформулированы требования: «отмены итогов сфальсифицированных выборов», «отставки Владимира Чурова и расследования его деятельности, расследования всех фактов нарушений и фальсификаций, наказания виновных», «проведения новых открытых и честных выборов». 23 декабря 2011 года Совет при Президенте РФ по развитию гражданского общества и правам человека констатировал, что «многочисленные сообщения о вбросах избирательных бюллетеней, переписывании протоколов об итогах голосования, необоснованном удалении наблюдателей и журналистов, запрете фотои видеосъемки, других нарушениях избирательных прав, а также необъяснимые парадоксы избирательной статистики вызывают массовое недоверие граждан к результатам выборов. Это влечет нравственную и политическую дискредитацию избирательной системы и сформированной на ее основе нижней палаты парламента, создает реальную угрозу российской государственности». Совет счел необходимым «обе-

\footnotetext{
${ }^{30}$ См.: Мебейн У., Калинин К. Электоральные фальсификации в России: комплексная диагностика выборов 2003-2004, 2007-2008 гг. // Российское электоральное обозрение. 2009. № 2. С. 57-70.

${ }^{31}$ См.: Любарев А. Выборы в Московскую городскую Думу: хроника деградации выборов // Российское электоральное обозрение. 2010. № 1. C. 72-83.
}

спечить скорейшее принятие нового избирательного законодательства с целью проведения на его основе досрочных парламентских выборов» $)^{32}$.

Расчеты показали, что из 32,4 млн. голосов, полученных «Единой Россией», «аномальными» являются 15,3 млн. ${ }^{33}$ Но, в отличие от предыдущих федеральных выборов, эти «аномальные» голоса существенно повлияли на результат. Если их исключить, «Единая Россия» получила бы не 238 мандатов, а 166, то есть лишилась бы большинства в Государственной Думе ${ }^{34}$. Впрочем, расчеты показывают, что «Единая Россия» лишается парламентского большинства, даже если счесть «вброшенными» только 3,6 млн. голосов.

Массовые акции протеста сыграли определенную роль. В Москве голосование и подсчет голосов на выборах Президента РФ 2012 года и выборах Мэра 2013 года обошлись без массовых нарушений. И это ко всему прочему добавило аргументы в пользу того, что итоги предыдущих голосований были фальсифицированы. Так, разброс результатов победителя по районам Москвы в 1999-2004 годах составлял 15-21\%. В 2005-2008 он резко вырос до 36-38\%, а в 2009 году составил $51 \%$ (от 34,3 до $85,5 \%$ ), в 2011 году $-43 \%$ (от 23,6 до 66,6\%). В 2012 году разброс вернулся к $20 \%$ (от 36,9 до $56,8 \%$ ); оказалось, что в 13 районах Южного административного округа Москвы В.В. Путин получил меньшую долю голосов, чем «Единая Россия», причем в районе Нагатино-Садовники разница составила $18,1 \%$. В 2013 году разброс составил 30\% (от 37,3 до 67,5\%).

Однако в ряде других регионов от порочной практики не отказались. И хотя на выборах Президента РФ 2012 года в целом уровень фальсификаций был ниже, чем прежде, все же количество «аномальных» голосов оказалось достаточно велико - 11 млн. Впрочем, из этих расчетов получилось, что В.В. Путин и без «аномальных» голосов победил бы в первом туре (55,3\% голосов вместо $65,3 \%)^{35}$.

\footnotetext{
${ }^{32}$ Решение Совета при Президенте Российской Федерации по развитию гражданского общества и правам человека от 23.12.2011 // Сайт Совета при Президенте РФ по развитию гражданского общества и правам человека (http://www.president-sovet.ru/ council_decision/council_statement/vibori_2011.php).

${ }_{33}$ См.: Шиилькин С. Математика выборов - 2011 // Троицкий вариант. 2011. № 25 (94). С. 2-4.

${ }^{34}$ См.: Бузин А.Ю., Вахштайн В.С., Кынев А.В., Любарев А.Е., Нисневич Ю.А., Савинцева М.И. Федеральные, региональные и местные выборы в России 4 декабря 2011 года: Аналитический доклад. М., 2012. С. 254-256.

${ }^{35}$ См.: Бузин А.Ю. Голосование и подсчет голосов // Выборы Президента России 4 марта 2012 года: Аналитический доклад. М., 2012. C. $101-140$.
} 


\section{Право и политика 13 (168) 2013}

На выборах, прошедших 8 сентября 2013 года, отличились Волгоград и Рязань, где несколько партий отказались признать результаты выборов в городские советы, ссылаясь на многочисленные факты фальсификаций ${ }^{36}$.

\section{«Сфабрикованное большинство»}

Термин «сфабрикованное большинство» был введен политологами для обозначения ситуации, когда какая-либо партия получает менее половины голосов избирателей, но при этом в силу особенностей избирательной системы ей достаются более половины депутатских мандатов ${ }^{37}$. Такая ситуация нарушает один из фундаментальных принципов демократии, сформулированный еще в статье 21 Всеобщей декларации прав человека: «Воля народа должна быть основой власти правительства; эта воля должна находить свое выражение в периодических и нефальсифицированных выборах .... $)^{38}$. Действительно, партия, получившая большинство мандатов, имеет возможность принимать решения без оглядки на позицию других партий; и если эта партия не получила поддержки большинства избирателей, она по сути будет проводить политику вопреки воле большинства народа.

В 1990-е годы в силу неразвитости партийной системы было сложно обсуждать результаты выборов с точки зрения адекватности партийного представительства. Так, из 219 депутатов, избранных 12 декабря 1993 года по одномандатным округам, 136 были «независимыми» (то есть были выдвинуты группами избирателей). 17 декабря 1995 года количество «независимых» депутатов (выдвинутых группами избирателей или в порядке самовыдвижения) снизилось до 77 (из 225), но 19 декабря 1999 года это число выросло до 105 (из 216). При этом ни одна партия на этих выборах не получала по одномандатным округам более 58 мандатов (рекорд у КПРФ в 1995 году).

Ситуация изменилась в 2003 году. «Единая Россия» получила по единому избирательному округу $37,6 \%$ голосов, но в списочной половине Государственной Думы ей досталось 120 мандатов (53,3\%). При этом

\footnotetext{
${ }^{36}$ См.: Периев A. «В урнах бюллетени лежали прямо в пачках» // Газета.py, 10.09.2013 (http://www.gazeta.ru/ politics/2013/09/10_a_5647361.shtml).

${ }^{37}$ См.: Голосов Г.В. Сфабрикованное большинство: конверсия голосов в места на думских выборах 2003 г. // ПОЛИС. 2005. № 1. C. $108-119$.

${ }^{38}$ См.: Всеобщая декларация прав человека // Международные избирательные стандарты: Сборник документов. М., 2004. С. 41-44.
}

ее кандидаты в одномандатных округах завоевали 103 мандата, и в целом партия получила 223 мандата, то есть 49,6\%. Однако затем во фракцию «Единой России» перешли большая часть из 67 депутатов, избиравшихся как «независимые», а также ряд депутатов, выдвинутых другими партиями. И в результате во фракции оказалось более двух третей депутатов. Таким образом, впервые в российской практике было реализовано «сфабрикованное большинство», хотя и на неформальной основе.

В 2007 году на выборах в Государственную Думу «Единая Россия» получила реальное большинство. В 2011 году ситуация оказалась на грани: 49,3\% от числа избирателей, принявших участие в голосовании, но $50,1 \%$ от числа действительных бюллетеней (другое дело, что этот результат, как отмечалось выше, достигнут благодаря фальсификациям).

В то же время региональные выборы, которые с декабря 2003 года повсеместно проводятся по смешанной или пропорциональной системе, дают нам много примеров «сфабрикованного большинства» ${ }^{39}$. Из 189 прошедших за это время кампаний «Единая Россия» получила «сфабрикованное большинство» в 62. Однако, если рассматривать только последние четыре года (с марта 2010 года по сентябрь 2013 года), когда популярность «Единой России» существенно снизилась и она стала гораздо реже получать более половины голосов, то вырисовывается несколько иная картина: из 75 кампаний «сфабрикованное большинство» получилось в 38 , то есть более чем в половине.

Похожая ситуация и на выборах в представительные органы административных центров регионов: из 41 кампании, прошедшей в 2010-2013 годах по пропорциональной или смешанной системе, «сфабрикованное большинство» получилось в 20.

Как показал наш анализ, главная причина такого явления - смешанная несвязанная избирательная система, позволяющая партии-лидеру получать сверхпредставительство за счет мажоритарной половины. Дополнительный вклад вносят также завышенный заградительный барьер (особенно в условиях, когда в выборах участвует большое число партий) и распределение мандатов по методу делителей Империали.

\footnotetext{
${ }^{39}$ См.: Любарев А.Е. Пропорциональная и смешанная избирательные системы на региональных и муниципальных выборах в Российской Федерации: проблемы «сфабрикованного большинства» // NB: Вопросы права и политики. 2013. № 8. С. 65-118; Кьнев А., Любарев А., Максимов А. Аналитический обзор № 4 по мониторингу избирательной кампании 8 сентября 2013: рождение новой парадигмы выборов // Сайт Комитета гражданских инициатив, 16.09.2013 (http://komitetgi.ru/analytics/848/).
} 
Являясь главным бенефициаром этих законодательных положений, «Единая Россия» не только не желает от них отказаться, но, напротив, стремится усугубить ситуацию. Снизив заградительный барьер до 5\% на федеральных и муниципальных выборах, законодатели сохранили на региональных выборах 7\%-ный барьер. Метод Империали получает все большее распространение на региональных и муниципальных выборах ${ }^{40}$. А искажение, достигаемое за счет мажоритарной составляющей, решено усилить, увеличив допустимую долю этой составляющей на региональных выборах с 50 до 75\%.

\section{Заключение}

Изложенный в данной статье материал свидетельствует, что российские выборы в основном не соответствуют своему конституционному предназначению - быть высшим непосредственным выражением власти народа.

Уже сам факт низкой активности избирателей на региональных и муниципальных выборах порождает сомнения в том, что результаты этих выборов отражают волю проживающих на этих территориях граждан. К тому же есть основания считать, что возрастной состав голосующих существенно отличается от возрастного состава граждан, имеющих право голоса, в сторону повышенной доли старшего поколения, то есть, образно говоря, результаты выборов направлены в прошлое, а не в будущее.

Однако в тех регионах, где официальные показатели активности высоки, возникают сомнения иного рода. На российских выборах в последнее десятилетие наблюдается закономерность: чем выше явка, тем выше и результат «Единой России», что свидетельствует о сильном влиянии административного ресурса. Полагаем, что невозможно считать свободными выборы, на которых одна партия получает более $75 \%$ голосов (в последнем избирательном цикле такие результаты показали 8 регионов).

В 2005-2011 годах российские граждане были лишены возможности выбирать глав регионов. В 2012 году эти выборы были восстановлены. Однако, если до 2004 года в результате губернаторских выборов хотя бы иногда происходила смена высшего должностного лица субъекта РФ (так, в 2003-2004 годах инкумбенты потерпели поражение в 6 из 36 кампаний), то в 2012-2013 годах во всех 13 кампаниях победили действующие

${ }^{40}$ См.: Кынев А., Любарев А. Правовые и политические особенности выборов 8 сентября 2013 г. // Сайт Комитета гражданских инициатив, 09.07.2013 (http://komitetgi.ru/analytics/713/). главы или исполняющие обязанности глав. При этом в четырех регионах незадолго до выборов был назначен новый исполняющий обязанности главы, который и был затем избран. Таким образом, получается, что смена власти происходит не в результате выборов, а выборы лишь легитимизируют ее. Этому способствует положение федерального закона, согласно которому выборы глав регионов могут происходить только в единый день голосования, даже в том случае, когда полномочия действующего главы прекращаются досрочно.

В целом мы видим, что «Единая Россия» в течение последних 10 лет удерживает власть практически повсеместно - на всех уровнях и во всех регионах (за исключением отдельных муниципальных образований). И выборы не приводят к сменяемости власти несмотря на экономический кризис, террористические акты, техногенные катастрофы и коррупционные скандалы. И несмотря на то, что «Единая Россия» получила менее половины голосов на последних выборах в Государственную Думу в 53 регионах, а на последних выборах региональных парламентов - в 46 регионах из 83.

Полагаем, что необходима комплексная реформа российского избирательного законодательства, включающая изменение порядка формирования избирательных комиссий (чтобы сделать их действительно независимыми от исполнительной власти), изменение правил регистрации кандидатов и списков кандидатов, переход к избирательным системам, более адекватно отражающим волю избирателей, и ряд других изменений. Проект такой реформы уже существует - это проект Избирательного кодекса РФ, подготовленный под руководством автора настоящей статьи ${ }^{41}$.

\section{Библиография:}

1. Бузин А.Ю., Вахштайн В.С., Кынев А.В., Любарев А.Е., Нисневич Ю.А., Савинцева М.И. Федеральные, региональные и местные выборы в России 4 декабря 2011 года: Аналитический доклад. М., 2012. C. $254-256$.

2. Бузин А.Ю., Любарев А.Е. Преступление без наказания: Административные технологии федеральных выборов 2007-2008 годов. М., 2008.

3. Голосов Г.В. Сфабрикованное большинство: конверсия голосов в места на думских выборах 2003 г. // ПОЛИС. 2005. № 1. С. 108-119.

\footnotetext{
${ }^{41}$ См.: Избирательный кодекс Российской Федерации - основа модернизации политической системы России / Под ред. А.Е. Любарева. М., 2011.
} 


\section{Право и политика 13 (168) • 2013}

4. Иванченко А.В., Любарев А.Е. Российские выборы от перестройки до суверенной демократии. M., 2007.

5. Кынев А., Любарев А. Правовые и политические особенности выборов 8 сентября 2013 г. // Сайт Комитета гражданских инициатив, 09.07.2013 (http://komitetgi.ru/analytics/713/).

6. Кынев А., Любарев А., Максимов А. Аналитический обзор № 4 по мониторингу избирательной кампании 8 сентября 2013: рождение новой парадигмы выборов // Сайт Комитета гражданских инициатив, 16.09.2013 (http://komitetgi.ru/analytics/848/).

7. Кынев А., Любарев А., Максимов А. Второй доклад по мониторингу избирательной кампании 8 сентября 2013. Итоги регистрации кандидатов: между борьбой за легитимность и страхом утраты контроля // Сайт Комитета гражданских инициатив, 14.08.2013 (http://komitetgi.ru/analytics/788/).

8. Кынев А., Максимов А. Аналитический обзор. Агитационная кампания и подготовка к дню голосования 8 сентября 2013: косвенная агитация, спойлерские и «маскировочные технологии» против технологической революции // Сайт Комитета гражданских инициатив, 02.08.2013 (http:// komitetgi.ru/analytics/827/).

9. Кынев А.В., Любарев А.Е. Партии и выборы в современной России: Эволюция и деволюция. М., 2011.

10. Любарев А. Выборы в Московскую городскую Думу: хроника деградации выборов // Российское электоральное обозрение. 2010. № 1. С. 72-83.

11. Любарев А.Е. Активность избирателей на федеральных, региональных и муниципальных выборах в Российской Федерации // NB: Проблемы общества и политики. 2013. № 8. С.138-209.

12. Любарев А.Е. Обеспечивает ли российское законодательство свободную конкуренцию на выборах? // Журнал о выборах. 2006. № 2. С. 53-57.

13. Любарев А.Е. Первые итоги партийной и избирательной реформ 2012 года // Сайт Комитета гражданских инициатив, 14.01.2013 (http://komitetgi.ru/ analytics/490/).

14. Любарев А.Е. Препятствия для свободной конкуренции на выборах: законодательство и правоприменительная практика // Российское электоральное обозрение. 2007. № 1. С. 20-28.

15. Любарев А.Е. Пропорциональная и смешанная избирательные системы на региональных и муниципальных выборах в Российской Федерации: проблемы «сфабрикованного большинства» // NB:
Вопросы права и политики. 2013. № 8. С. 65-118.

16. Любарев А.Е. Регулирование избирательной системы в законодательстве субъектов Российской Федерации // Российский юридический журнал. 2010. № 4. С. 76-82.

17. Любарев А.Е. Регулирование избирательной системы, применяемой на муниципальных выборах, в законах субъектов РФ // Муниципальная Россия. 2011. № 8. C. 57-70.

18. Любарев А.Е. Хронология изменений российского избирательного законодательства, 1988-2013 // Сайт Центра «Геликс» (http://www.geliks.org/index. php?option=com_content\&task=view\&id=1558\&Ite $\operatorname{mid}=431$ ).

19. Любарев А.Е. Является ли численность партии индикатором ее общественной поддержки // Право и политика. 2010. № 3. С. 462-469.

20. Любарев А.Е., Бузин А.Ю., Кынев А.В. Мертвые души: Методы фальсификации итогов голосования и борьба с ними. М., 2007. С. 19-39.

21. Любарев А.Е., Шалаев Н.Е. О критерии пропорциональности при распределении мандатов между партийными списками // Конституционное и муниципальное право. 2009. № 23. С. 23-27.

22. Мебейн У., Калинин К. Электоральные фальсификации в России: комплексная диагностика выборов 2003-2004, 2007-2008 гг. // Российское электоральное обозрение. 2009. № 2. С. 57-70.

23. Орешкин Д.Б. Электоральная демократия и целостность политического пространства России // Журнал о выборах. 2001. № 2. С. 28-33.

24. Постников А.Е. Новый проект Федерального закона «Об основных гарантиях избирательных прав и права на участие в референдуме граждан Российской Федерации»: минусы и плюсы // Материалы «круглого стола» по обсуждению законопроекта «О внесении изменений и дополнений в Федеральный закон «Об основных гарантиях избирательных прав и права на участие в референдуме граждан Российской Федерации». Москва, 2002. C. 6-25.

25. Прибыловский В. Управляемые выборы: Деградация выборов при Путине // Россия Путина: История болезни. М., 2004. С. 6-85.

26. Шейнис В.Л. Избирательное законодательство и избирательная практика в системе российских государственных институтов // Конституционный вестник. 2008. № 1 (19). С. 214-230.

27. Шпилькин С. Математика выборов - $2011 / /$ Троицкий вариант. 2011. № 25 (94). С. 2-4 
DOI: $10.7256 / 1811-9018.2013 .13 .10158$

При цитировании этой статьи сноска на dоі обязательна

Дискуссионная трибуна

\section{References (transliteration):}

1. Buzin A.Yu., Vakhshtain V.S., Kynev A.V., Lyubarev A.E., Nisnevich Yu.A., Savintseva M.I. Federal'nye, regional'nye i mestnye vybory v Rossii 4 dekabrya 2011 goda: Analiticheskii doklad. M., 2012. S. 254-256.

2. Buzin A.Yu., Lyubarev A.E. Prestuplenie bez nakazaniya: Administrativnye tekhnologii federal'nykh vyborov 2007-2008 godov. M., 2008.

3. Golosov G.V. Sfabrikovannoe bol'shinstvo: konversiya golosov v mesta na dumskikh vyborakh 2003 g. // POLIS. 2005. № 1. S. 108-119.

4. Ivanchenko A.V., Lyubarev A.E. Rossiiskie vybory ot perestroiki do suverennoi demokratii. M., 2007.

5. Kynev A., Lyubarev A. Pravovye i politicheskie osobennosti vyborov 8 sentyabrya 2013 g. // Sait Komiteta grazhdanskikh initsiativ, 09.07.2013 (http://komitetgi. ru/analytics/713/).

6. Kynev A., Lyubarev A., Maksimov A. Analiticheskii obzor № 4 po monitoringu izbiratel'noi kampanii 8 sentyabrya 2013: rozhdenie novoi paradigmy vyborov // Sait Komiteta grazhdanskikh initsiativ, 16.09.2013 (http://komitetgi.ru/analytics/848/).

7. Kynev A., Lyubarev A., Maksimov A. Vtoroi doklad po monitoringu izbiratel'noi kampanii 8 sentyabrya 2013. Itogi registratsii kandidatov: mezhdu bor'boi za legitimnost' i strakhom utraty kontrolya // Sait Komiteta grazhdanskikh initsiativ, 14.08.2013 (http:// komitetgi.ru/analytics/788/).

8. Kynev A., Maksimov A. Analiticheskii obzor. Agitatsionnaya kampaniya i podgotovka $\mathrm{k}$ dnyu golosovaniya 8 sentyabrya 2013: kosvennaya agitatsiya, spoilerskie i «maskirovochnye tekhnologii» protiv tekhnologicheskoi revolyutsii // Sait Komiteta grazhdanskikh initsiativ, 02.08.2013 (http://komitetgi.ru/analytics/827/).

9. Kynev A.V., Lyubarev A.E. Partii i vybory v sovremennoi Rossii: Evolyutsiya i devolyutsiya. M., 2011.

10. Lyubarev A. Vybory v Moskovskuyu gorodskuyu Dumu: khronika degradatsii vyborov // Rossiiskoe elektoral'noe obozrenie. 2010. № 1. S. 72-83.

11. Lyubarev A.E. Aktivnost' izbiratelei na federal'nykh, regional'nykh i munitsipal'nykh vyborakh v Rossiiskoi Federatsii // NB: Problemy obshchestva i politiki. 2013. № 8. S.138-209.

12. Lyubarev A.E. Obespechivaet li rossiiskoe zakonodatel'stvo svobodnuyu konkurentsiyu na vyborakh? // Zhurnal o vyborakh. 2006. № 2. S. 53-57.

13. Lyubarev A.E. Pervye itogi partiinoi i izbiratel'noi reform 2012 goda // Sait Komiteta grazhdanskikh initsiativ, 14.01.2013 (http://komitetgi.ru/analytics/490/).
14. Lyubarev A.E. Prepyatstviya dlya svobodnoi konkurentsii na vyborakh: zakonodatel'stvo i pravoprimenitel'naya praktika // Rossiiskoe elektoral'noe obozrenie. 2007. № 1. S. 20-28.

15. Lyubarev A.E. Proportsional'naya i smeshannaya izbiratel'nye sistemy na regional'nykh i munitsipal'nykh vyborakh v Rossiiskoi Federatsii: problemy «sfabrikovannogo bol'shinstva»// NB: Voprosy prava i politiki. 2013. № 8. S. 65-118.

16. Lyubarev A.E. Regulirovanie izbiratel'noi sistemy v zakonodatel'stve sub'ektov Rossiiskoi Federatsii // Rossiiskii yuridicheskii zhurnal. 2010. № 4. S. 76-82.

17. Lyubarev A.E. Regulirovanie izbiratel'noi sistemy, primenyaemoi na munitsipal'nykh vyborakh, v zakonakh sub"ektov RF // Munitsipal'naya Rossiya. 2011. № 8. S. 57-70.

18. Lyubarev A.E. Khronologiya izmenenii rossiiskogo izbiratel'nogo zakonodatel'stva, 1988-2013 // Sait Tsentra «Geliks» (http://www.geliks.org/index.php?option=com content\&task=view\&id=1558\&Itemid=431).

19. Lyubarev A.E. Yavlyaetsya li chislennost' partii indikatorom ee obshchestvennoi podderzhki // Pravo i politika. 2010. № 3. S. 462-469.

20. Lyubarev A.E., Buzin A.Yu., Kynev A.V. Mertvye dushi: Metody fal'sifikatsii itogov golosovaniya i bor'ba s nimi. M., 2007. S. 19-39.

21. Lyubarev A.E., Shalaev N.E. O kriterii proportsional'nosti pri raspredelenii mandatov mezhdu partiinymi spiskami // Konstitutsionnoe imunitsipal'noe pravo. 2009. №23. S. 23-27.

22. Mebein U., Kalinin K. Elektoral'nye fal'sifikatsii v Rossii: kompleksnaya diagnostika vyborov 2003-2004, 2007-2008 gg. // Rossiiskoe elektoral'noe obozrenie. 2009. № 2. S. 57-70.

23. Oreshkin D.B. Elektoral'naya demokratiya i tselostnost' politicheskogo prostranstva Rossii // Zhurnal o vyborakh. 2001. № 2. S. 28-33.

24. Postnikov A.E. Novyi proekt Federal'nogo zakona «Ob osnovnykh garantiyakh izbiratel'nykh prav i prava na uchastie v referendume grazhdan Rossiiskoi Federatsii»: minusy i plyusy // Materialy «kruglogo stola» po obsuzhdeniyu zakonoproekta «O vnesenii izmenenii i dopolnenii v Federal'nyi zakon «Ob osnovnykh garantiyakh izbiratel'nykh prav i prava na uchastie v referendume grazhdan Rossiiskoi Federatsii». Moskva, 2002. S. 6-25.

25. Pribylovskii V. Upravlyaemye vybory: Degradatsiya vyborov pri Putine // Rossiya Putina: Istoriya bolezni. M., 2004. S. 6-85.

26. Sheinis V.L. Izbiratel'noe zakonodatel'stvo i izbiratel'naya praktika v sisteme rossiiskikh gosudarstvennykh institutov // Konstitutsionnyi vestnik. 2008. № 1 (19). S. 214-230.

27. Shpil'kin S. Matematika vyborov - 2011 // Troitskii variant. 2011. № 25 (94). S. 2-4 